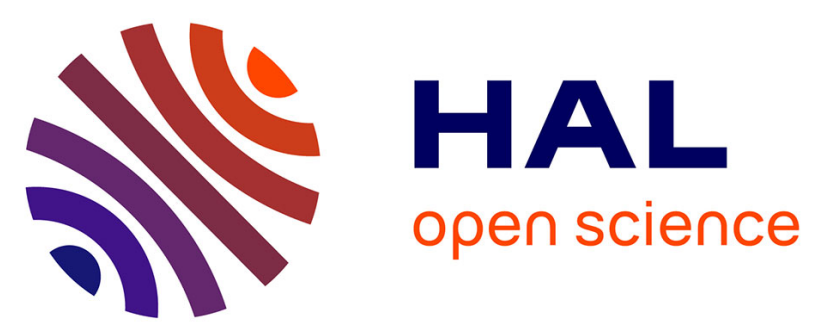

\title{
Non-clinical interventions to prevent postpartum haemorrhage and improve its management: A systematic review
}

Laurent Gaucher, Pauline Occelli, Catherine Deneux-Tharaux, Cyrille Colin, Pascal Gaucherand, Sandrine Touzet, Corinne Dupont

\section{To cite this version:}

Laurent Gaucher, Pauline Occelli, Catherine Deneux-Tharaux, Cyrille Colin, Pascal Gaucherand, et al.. Non-clinical interventions to prevent postpartum haemorrhage and improve its management: A systematic review. European Journal of Obstetrics \& Gynecology and Reproductive Biology, 2019, 240, pp.300 - 309. 10.1016/j.ejogrb.2019.07.018 . hal-03487489

\section{HAL Id: hal-03487489 \\ https://hal.science/hal-03487489}

Submitted on 20 Dec 2021

HAL is a multi-disciplinary open access archive for the deposit and dissemination of scientific research documents, whether they are published or not. The documents may come from teaching and research institutions in France or abroad, or from public or private research centers.
L'archive ouverte pluridisciplinaire HAL, est destinée au dépôt et à la diffusion de documents scientifiques de niveau recherche, publiés ou non, émanant des établissements d'enseignement et de recherche français ou étrangers, des laboratoires publics ou privés.

\section{(ㅇ)(1) $\$$}

Distributed under a Creative Commons Attribution - NonCommerciall 4.0 International 


\section{TITLE PAGE}

Non-clinical interventions to prevent postpartum haemorrhage and improve its management: a systematic review

Laurent Gaucher ${ }^{1,2}$, Pauline Occelli ${ }^{2,3}$, Catherine Deneux-Tharaux ${ }^{4}$, Cyrille Colin ${ }^{2,3}$, Pascal Gaucherand $^{1,2}$, Sandrine Touzet ${ }^{2,3}$, Corinne Dupont ${ }^{2,5}$.

1. Hospices Civils de Lyon, Hôpital Femme - Mère-Enfant, F-69500 Bron, France;

2. Univ. Lyon, University Claude Bernard Lyon 1, Health Services and Performance Research HESPER EA 7425, F-69008 Lyon, France;

3. Hospices Civils de Lyon, Pôle de Santé Publique, F-69003 Lyon, France;

4. Inserm U1153, Obstetrical, Perinatal and Pediatric Epidemiology Research Team, Centre for Epidemiology and Statistics Sorbonne Paris Cité, DHU Risks in pregnancy, F-75004 Paris Descartes University;

5. Réseau périnatal Aurore, F-69004 Lyon, France.

Contribution to authorship: LG and CD participated in the design, data acquisition and analysis, and drafting of the article. PO, CD-T, and ST participated in the design, data analysis and drafting of the article. CC and PG participated in revising the draft paper.

\section{Corresponding author:}

Laurent Gaucher

Address: 162 Av Lacassagne 69003 Lyon, France

Telephone number: +33679032848

Fax number: +33427856805

\section{E-MAIL ADDRESS: LAURENT.GAUCHER@CHU-LYON.FR}




\section{STANDARD ABSTRACT}

Postpartum haemorrhages (PPHs) account for around 200 deaths per year in the developed regions of the world. However, the efficacy of pharmacological and clinical interventions to prevent or manage PPHs is well established.

Our objective was to determine the effectiveness of non-clinical interventions targeting healthcare professionals, organisations or facilities in preventing PPH or improving its management.

We conducted a systematic review using the PRISMA four-step model. The MEDLINE and Cochrane databases were searched up to March 2019. Inclusion criteria were interventional studies, published in English of French language, aiming to reduce PPH outcomes for women in hospitals, regardless of study design. The studies' methodological quality was assessed according to the Cochrane EPOC criteria.

We found 32 studies that met the inclusion criteria. None met all the methodological quality criteria. Six types of non-clinical interventions were identified: guideline dissemination, audit with feedback, simulation, training, clinical pathway and multifaceted interventions. Eleven studies reported a significant reduction in PPH rates and/or its complications, five studies reported a significant increase and 16 studies no significant results.

The heterogeneity of the studies prevents us from identifying an effective non-clinical intervention in reducing PPH rates.

Funding: No funding

Keywords: obstetric haemorrhage; health services research; non-clinical interventions; medical education; systematic reviews.

Abstract word count: 189. 


\section{INTRODUCTION}

Haemorrhage is the leading cause of maternal mortality worldwide [1]. With one-fifth of all maternal deaths classified as postpartum haemorrhages (PPHs), it is the most common pregnancy-related complication, resulting in more than 80000 deaths per year [1]. These deaths are concentrated in regions with low levels of economic development, which is the main factor determining the risk of maternal death; one explanation is that many women deliver at home and are often attended by unskilled healthcare providers $[1,2]$. However, developed regions are not spared, with around 200 deaths per year attributable to PPH in hospitals [1].

A hospital environment with skilled personnel facilitates PPH prevention and management [3]. Associations of healthcare professionals regularly publish and update clinical guidelines on the pharmacological and/or surgical prevention and management of PPH in hospitals [4-9]. The efficacy and safety of pharmacological interventions for the prevention and management of PPH have been established for some time $[10,11]$. Improving prevention should reduce the overall rates (minor or major) of PPH, while improved management should reduce the rate of major PPH and of these complications, especially mortality and serious morbidity. In UK and Republic of Ireland, improvements in care might have made a difference in the outcomes of almost $60 \%$ of the 18 women who died from PPH or amniotic fluid embolism during the 2013-15 period [12]. In France, all 23 maternal haemorrhage-related deaths between 2010 and 2012 were "avoidable" (13/23) or "possibly avoidable" (10/23), with none considered inevitable by the national committee of independent experts [13]. The potential for reducing the number of deaths from haemorrhage is clear. The partial application of the guidelines suggests that an improvement in prevention and management of PPH is feasible [14-17].

Translating guidelines from research findings to clinical practice is a long-standing concern [18]. This translation can be done through non-clinical intervention programs but only one Cochrane review targeting non-clinical interventions on an obstetrical topic was published and it was focused on unnecessary caesarean section [19]. To the best of our knowledge, no systematic review of the 
74 literature describes the characteristics of non-clinical interventions for the prevention and 75 management of PPH and their efficacy in a hospital environment. The objective of the present study 76 was therefore to determine the effectiveness of non-clinical interventions in preventing PPH and 77 improving its management. 


\section{MATERIAL AND METHODS}

We conducted a systematic literature review in four steps in accordance with the recommendations of the PRISMA Statement (Figure 1) [20,21]. In the first step, records were identified in the MEDLINE (via PubMed) and Cochrane databases from their inception through March 2019, by linking terms describing non-clinical interventions and to those describing PPH outcomes (Appendix S1). Nonclinical interventions refer to "interventions applied independently of a clinical encounter between a particular provider and patient in the context of patient care" [22]. They target women (e.g. implementation of a preventive clinical pathway), healthcare professionals (e.g. implementation of clinical practice guidelines) or healthcare organisations (e.g. establishment of a task force...). The search was restricted to records in English or French. The initial search of with MeSH terms was completed with a search in all field terms to take into account the six-month gap required for indexing in MeSH. Authors' personal knowledge was also used to identify records The snowball method was used to find new articles [23]. In the second step, two reviewers (LG and CD) independently screened the titles and abstracts of all records for eligibility. In the event of disagreement between the reviewers, records were deemed eligible. We included studies reporting PPH outcomes, as a primary or secondary outcome, for facility-based births, regardless of population, intervention or group of comparison. We excluded studies with no statistical analysis of the intervention's effect, no control group, investigating home births or aiming to improve women's access to hospital facilities. Commentaries (i.e., letters to the editor or editorials), protocols and description of programmes with no implementation were also excluded. Both reviewers (LG and CD) read the eligible articles in full. In case of disagreement, they discussed the article until reaching a consensus, if necessary by discussion with two other authors (PO and ST). In a fourth and final step, both reviewers (LG and CD) independently analysed each of the included studies, using a standardised data collection form. The methodological quality criteria, the study design, the content of the intervention and its efficacy were systematically retrieved. 
The methodological quality was summarised with the scale developed by the Cochrane Effective

105 Practice and Organisation of Care (EPOC) Review Group [24]. PPH rates (as a primary or secondary

106 outcome) were considered reliable when they were based on a systematic measurement (with collection bag or weighing) or an objective criterion (number of deaths, or number of transfusions as a process outcome).

The description of non-clinical interventions included the country where the study took place, the number of women included according to the mode of delivery (caesarean section - CS, or vaginal delivery - VD), its objective (prevention of $\mathrm{PPH}$, management of $\mathrm{PPH}$, or both), the type of intervention, implementation period, evaluation period, accumulated post-intervention period

113 (defined as the sum of the implementation and the evaluation periods), and the proportion of 114 professionals involved.

115 The economy of the country of study was classified as developed, in transition, or developing, 116 according to the United Nations classification [25]. The severity of the PPH was categorised as minor $117(500-1000 \mathrm{ml})$ or major $(>1000 \mathrm{ml})$, as recommended by the Royal College of Obstetricians and 118 Gynaecologists (RCOG) to differentiate the effects of non-clinical interventions on prevention from 119 those on PPH management [26]. 


\section{Search strategy}

122 The electronic search and personal knowledge yielded a total of 520 records after removal of duplicates. From these, review of the full text of these publications showed that 32 studies met the inclusion criteria (Figure 1). Records identified through the MEDLINE database are available at https://www.ncbi.nlm.nih.gov/sites/myncbi/1nU7sizTmqy5r/collections/58024547/public/.

\section{Quality assessment of the studies}

128

No study met all EPOC criteria. Four studies were cluster randomised trials (RCTs) and 28 before-after studies. Of the four RCTs, one had PPH rates as its primary outcome [27]. Of the 28 before-after studies, 4 had objective PPH rates measures as their primary outcome [28-31]. The most common bias of the RCTs was the risk of contamination between groups, which affected 3 of the 4 trials [3234]; among the 28 before-after studies, the most frequent source of bias was the lack of consideration by 14 studies of the spontaneous improvement of the characteristics of study and control groups (Table 1) [28,29,35-42]. Three before-after study included a contemporary control group from the implementation time to the measurement of the outcome $[31,43,44]$. PPH criteria differed between studies: blood loss $(n=18)$, process outcomes $(n=12)$, or both $(n=1)$; one study did not define the criterion [34]. The methods used to quantify blood loss were only visually estimates $(n=5)$ or measurement $(n=5)$, the latter by collecting blood in a calibrated bag or by weighing the blood and collecting materials (drapes, dressings, napkins, etc.) [39,45]. Eight studies did not specify the method used to quantify blood loss and for one study the measurement method had changed between the observation and intervention period (Table 2).

\section{Description of non-clinical interventions}

The studies were published from 2004 to 2018; 11 studies were conducted in Europe, 9 in the USA, 2 in Australia, 3 in Latin America, 5 in Africa and 2 in Asia. The number of patients included ranged 

place in more (range: 2-105 maternity units). In all, 26 studies concerned PPH after all deliveries (VD and CS), while 5 examined PPH only after VD, and 1 after CS only (Table 2).

Four studies aimed to improve the prevention of PPH, 11 to improve the management of PPH after diagnosis and 17 both to prevent and manage it. Implementation periods ranged from one day to eight years. Interventions were implemented before their evaluation in 15 studies, conducted simultaneously with its evaluation in 14 more, and mixed (with a refresher course) in 3 . Evaluation periods ranged from two months to eight years post-intervention, with 1-21 time points for measurement. The accumulated post-intervention time ranged from two months to eight years. Six studies reported the proportion of clinicians trained relative to the total number of staff targeted; it ranged from $14 \%$ to $100 \%[29,30,34,35,43,46]$. Eleven studies stated the percentage of professionals trained without specifying a denominator, and 13 did not mention the number of trained professionals. Only Nelissen et al. reported the number of births assisted by trained staff (Table 3) [46].

PPH was the only obstetric complication targeted by the intervention in 26 studies; among the remaining 6, it was associated with the implementation of a guideline for the management of other emergency situations $[27,31,34,37,44,47]$. The interventions tested were a pathway (early warning trigger tool; $n=1)$, dissemination of guidelines $(n=2)$, audit feedback $(n=3)$, simulation (in a simulation centre $n=6$, on-site $n=4)$, training $(n=5)$ and multifaceted interventions (i.e., an intervention with more than one component; the number of components in the 11 such studies reviewed here ranged from 3 to 7). Details of the content of the interventions are presented in Appendix S2.

\section{Efficacy according to study design and intervention type}

169 Eleven studies reported a significant reduction of PPH rates after implementation of the non-clinical 170 interventions. Five studies reported a significant increase in PPH rates as a result of the non-clinical 171 intervention intended to reduce it, and 16 studies did not significantly modify PPH rates. A significant 
reduction in PPH rates was observed in 1 of the 4 RCTs and 10 of the 28 before-after studies. The sample size required was estimated in six studies, including four that reported significant results $[27,30,31,46]$. PPH rates fell significantly in 5 of the 9 studies conducted in developing economies (Africa, Asia, and Latin America), not in the only study conducted in a transitioning economy (Kazakhstan), and in 6 of the 22 in developed economies (Table 2). The same types of interventions were implemented regardless of the country's level of development (Appendix S2). Of the 26 studies including both VD and CS populations, 7 found a significant reduction in the PPH rates, as did 4 of the 5 studies including an exclusively VD population; the study of an exclusively CS population did not. Among the eleven studies that reported minor PPH outcomes, four found a significant reduction in PPH rates $[27,45,46,48]$, while of the twenty two that reported major PPH outcomes, nine found significant reductions (Table 2) $[27,28,30,35,39,40,45,48,49]$. Of the four studies targeting only PPH prevention, two had focused on the rate of minor PPH and one of them showed a significant reduction [27]. Of the 11 studies targeting only PPH management, 7 focused on the major PPH rate and 2 found that it fell significantly [30,35]. Among the 17 studies that targeted prevention and management, PPH rates declined in 2 of the 4 examining minor PPH rates, 3 of the 7 looking at major PPH rates and 2 of the 5 assessing all PPH (Table 2 and 3 ).

Only one study tested the impact of a clinical pathway using an early warning trigger tool and didn't report a significant reduction of PPH. Neither of the 2 studies that used simple guideline dissemination as an intervention reported a significant drop in PPH rates. Two of five studies that used training as intervention did significantly reduce these rates. Of ten studies that used simulation training as intervention, four were associated with significantly lower PPH rates, as were all three studies that used audit and feedback as an intervention. Among the 11 multifaceted interventions reported, 2 reported a significant decline of PPH. No relation was found between efficacy and the number of components or any specific component of multifaceted interventions. For example, Althabe et al. reported a significant reduction of PPH rates in an intervention with seven components, as did Dumont et al. with only two [27,32]. The period of intervention implementation 
198 appeared to be longer in the 12 studies reporting a positive impact (median interquartile range [IQR]:

1999 [2-29] months) than in the 15 that did not (4 [1-13] months); the accumulated post-intervention

200 time was also greater in the positive studies (median [IQR]: 27 [15-39] months vs. 14 [12-24]

201 months, respectively). Of the nineteen studies reporting the number of trainees, seven showed a

202 significant reduction in PPH rates $[30,35,39,40,46,49,50]$. 
204 This systematic review included only 32 published studies evaluating the efficacy of non-clinical 205 interventions aimed at preventing and/or managing PPH. Overall the methodological quality and/or reporting was poor. Although nearly one third of these studies reported a significant benefit from non-clinical interventions, an half reported no significant difference, and five a significant negative impact. It should be noted, however, that no study that used simple guideline dissemination reported significant results.

A relatively small number of published studies have evaluated the efficacy of non-clinical interventions targeting PPH in a hospital environment. This finding is surprising given the number of maternal deaths due to PPH and the fact that almost all deaths due to haemorrhage are believed to be potentially preventable $[13,51]$. Furthermore, the methodological failings of these publications indicates the need for further studies on this topic, with the exception of studies of simple guideline dissemination, long known to be ineffective [52].

The Medical Research Council (MRC) has published recommendations about experimental designs for evaluating complex interventions [53-55]. These recommendations are very broad and must be adapted to the local context of each medical team. However, our literature review leads us to emphasise the importance of two specific recommendations of the MRC guidance. First, experimental designs are preferred because they make it possible to avoid confounding the secular evolution of medical practices, that is, trends over time, which are likely to influence the rate of PPH independently of the intervention (e. g., induction of labour, prophylactic use of oxytocin, etc.). This was the principal bias in the studies we reviewed. Secondly, the evaluation of process outcomes may provide information about the functioning of non-clinical interventions, but it does not replace PPH outcomes, which remain the clinical objective. They were, however, the primary endpoint for fewer than half the studies included here. Furthermore, the choice of outcome must be linked to the

227 objective of the intervention. The minor PPH rate is appropriate for evaluating interventions 228 intended to improve prevention while PPH complications, such as the major PPH rate, are 
appropriate for assessing interventions aimed at improving PPH management. In this review, only half the studies used the right rate (minor or major) of $\mathrm{PPH}$ to evaluate a prevention or a management programme.

In addition to the choice of minor or major PPH rates as outcomes, it is important to define how to measure it. The recent core outcome sets propose that blood loss be measured to evaluate PPH rates but fail to define how $[56,57]$. In our experience, one important difficulty of measuring blood loss to characterise PPH is that it requires a certain period of practice to be able to do so accurately. This point may explain the increases in PPH rates over time in the studies by Skupski et al. and Einerson el al. $[58,59]$. A more rapidly reliable method is the shock index, based on medical constants and first described in 1976 but only recently applied to the postpartum period [60,61].

Another potentially interesting result is that the median period of intervention implementation of the studies that found a significant decrease in PPH rates was higher than that of those that did not; however further studies are required for conclusions to be drawn. It is currently impossible to isolate this potential result from the secular evolution of medical practices. A more general point is that the insufficient quality of reporting does not allow clinicians or health decision-makers to judge the applicability of published studies to their local context. One explanation for this finding may be the lack of specific recommendations for reporting non-clinical interventions, but the authors of future studies could use the MRC guidance and Criteria for Reporting the Development and Evaluation of Complex Interventions in healthcare: revised guideline (CReDECl 2) recommendations to improve reporting quality $[55,62,63]$. The MRC and NIHR have jointly commissioned an update of the MRC guidance to be published in 2019 .

The strength of this study lies in its search algorithm, which used a broad range of terms, without restriction to a particular period or economic development level. This is underlined by the very few articles identified only through personal knowledge or snowballing. The literature review was, however, limited by its restriction to published studies, in English or French, referenced in MEDLINE or the Cochrane Database. 


\section{CONCLUSION}

257 International research about non-clinical interventions for improving the prevention and 258 management of PPH suffers from a severe lack of studies on this major public health issue, especially 259 compared to the many clinical studies published. Investigators should be encouraged to conduct 260 non-clinical interventions and to report all these elements with great rigour. This would allow other 261 obstetric teams to benefit from these studies. 
263 We thank Marion Cortet, Cyril Huissoud, René-Charles Rudigoz, Antoine Duclos and Alexandre 264 Dumont for their careful review of the manuscript. We thank Philip Robinson (Direction de la

265 Recherche Clinique et de l'Innovation, Hospices Civils de Lyon) for help in manuscript preparation, Jo 266 Ann Cahn for improving our English, and Esther Bacherot, Florence Bouriot, and Marie-Agnes Faure 267 (Documentation Centrale, Hospices Civils de Lyon) for help in documentary research.

268

\section{Disclosure of Interests}

270 The authors whose names are listed immediately below certify that they have NO affiliations with or 271 involvement in any organisation or entity with any financial interest (such as honoraria; educational 272 grants; participation in speakers' bureaus; membership, employment, consultancies, stock 273 ownership, or other equity interest; and expert testimony or patent-licensing arrangements), or non274 financial interest (such as personal or professional relationships, affiliations, knowledge or beliefs) in 275 the subject matter of these research article.

\section{Details of ethics approval}

278 N/A. As this was a systematic review, formal ethical approval was not required.

279

Funding

281

None 


\section{References}

[1] Say L, Chou D, Gemmill A, Tunçalp Ö, Moller A-B, Daniels J, et al. Global causes of maternal death: a WHO systematic analysis. Lancet Glob Health 2014;2:e323-33. doi:10.1016/S2214109X(14)70227-X.

[2] Walraven G, Wanyonyi S, Stones W. Management of post-partum hemorrhage in low-income countries. Best Pract Res Clin Obstet Gynaecol 2008;22:1013-23. doi:10.1016/j.bpobgyn.2008.08.002.

[3] Weeks A. The prevention and treatment of postpartum haemorrhage: what do we know, and where do we go to next? BJOG Int J Obstet Gynaecol 2015;122:202-10. doi:10.1111/14710528.13098.

[4] American College of Obstetricians and Gynecologists. ACOG Practice Bulletin: Clinical Management Guidelines for Obstetrician-Gynecologists Number 76, October 2006: postpartum hemorrhage. Obstet Gynecol 2006;108:1039-47.

[5] Leduc D, Senikas V, Lalonde AB, Ballerman C, Biringer A, Delaney M, et al. Active management of the third stage of labour: prevention and treatment of postpartum hemorrhage. J Obstet Gynaecol Can JOGC J Obstétrique Gynécologie Can JOGC 2009;31:980-93.

[6] Lalonde A, International Federation of Gynecology and Obstetrics. Prevention and treatment of postpartum hemorrhage in low-resource settings. Int J Gynaecol Obstet Off Organ Int Fed Gynaecol Obstet 2012;117:108-18. doi:10.1016/j.ijgo.2012.03.001.

[7] World Health Organization. WHO recommendations for the prevention and treatment of postpartum haemorrhage. Geneva, Switzerland: 2012.

[8] Committee on Practice Bulletins-Obstetrics. Practice Bulletin No. 183: Postpartum Hemorrhage. Obstet Gynecol 2017;130:e168-86. doi:10.1097/AOG.0000000000002351.

[9] Dupont C, Ducloy-Bouthors A-S, Huissoud C. [Clinical and pharmacological procedures for the prevention of postpartum haemorrhage in the third stage of labor]. J Gynecol Obstet Biol Reprod (Paris) 2014;43:966-97. doi:10.1016/j.jgyn.2014.09.025.

[10] Gallos ID, Williams HM, Price MJ, Merriel A, Gee H, Lissauer D, et al. Uterotonic agents for preventing postpartum haemorrhage: a network meta-analysis. Cochrane Database Syst Rev 2018;4:CD011689. doi:10.1002/14651858.CD011689.pub2.

[11] Mousa HA, Blum J, Abou El Senoun G, Shakur H, Alfirevic Z. Treatment for primary postpartum haemorrhage. Cochrane Database Syst Rev 2014:CD003249. doi:10.1002/14651858.CD003249.pub3.

[12] Knight M, Nair M, Tuffnell D, Shakespeare J, Kenyon S, Kurinczuk J, et al. Saving Lives, Improving Mothers' Care - Lessons learned to inform maternity care from the UK and Ireland Confidential Enquiries into Maternal Deaths and Morbidity 2013-15. Oxford: National Perinatal Epidemiology Unit; 2017.

[13] Deneux-Tharaux C, Saucedo M. Les morts maternelles en France : mieux comprendre pour mieux prévenir. 5e rapport de l'Enquête nationale confidentielle sur les morts maternelles (ENCMM) 2010-2012. Saint-Maurice, France: Santé Publique France; 2017.

[14] Kacmar RM, Mhyre JM, Scavone BM, Fuller AJ, Toledo P. The use of postpartum hemorrhage protocols in United States academic obstetric anesthesia units. Anesth Analg 2014;119:906-10. doi:10.1213/ANE.0000000000000399.

[15] Dupont C, Deneux-Tharaux C, Cortet M, Colin C, Touzet S, Rabilloud M, et al. [Practices for management of grave postpartum haemorrhage after vaginal delivery: a population-based study in 106 French maternity units]. J Gynécologie Obstétrique Biol Reprod 2012;41:279-89. doi:10.1016/j.jgyn.2012.02.001.

[16] Imamura M, Kanguru L, Penfold S, Stokes T, Camosso-Stefinovic J, Shaw B, et al. A systematic review of implementation strategies to deliver guidelines on obstetric care practice in low- and middle-income countries. Int J Gynaecol Obstet Off Organ Int Fed Gynaecol Obstet 2017;136:19-28. doi:10.1002/ijgo.12005. 
[17] Blondel B, Gonzalez L, Raynaud P. Enquête nationale périnatale 2016. Les naissances et les établissements, situation et évolution depuis 2010 - Rapports - Ministère des Solidarités et de la Santé. 2016.

[18] Lenfant C. Shattuck lecture--clinical research to clinical practice--lost in translation? N Engl J Med 2003;349:868-74. doi:10.1056/NEJMsa035507.

[19] Chen I, Opiyo N, Tavender E, Mortazhejri S, Rader T, Petkovic J, et al. Non-clinical interventions for reducing unnecessary caesarean section. Cochrane Database Syst Rev 2018;9:CD005528. doi:10.1002/14651858.CD005528.pub3.

[20] Liberati A, Altman DG, Tetzlaff J, Mulrow C, Gotzsche PC, loannidis JPA, et al. The PRISMA statement for reporting systematic reviews and meta-analyses of studies that evaluate healthcare interventions: explanation and elaboration. BMJ 2009;339:b2700-b2700. doi:10.1136/bmj.b2700.

[21] Moher D, Liberati A, Tetzlaff J, Altman DG, PRISMA Group. Preferred reporting items for systematic reviews and meta-analyses: the PRISMA statement. PLoS Med 2009;6:e1000097. doi:10.1371/journal.pmed.1000097.

[22] World Health Organization. WHO recommendations. Non-clinical interventions to reduce unnecessary caesarean sections. 2018.

[23] Greenhalgh T, Peacock R. Effectiveness and efficiency of search methods in systematic reviews of complex evidence: audit of primary sources. BMJ 2005;331:1064-5. doi:10.1136/bmj.38636.593461.68.

[24] Grimshaw JM, Thomas RE, MacLennan G, Fraser C, Ramsay CR, Vale L, et al. Effectiveness and efficiency of guideline dissemination and implementation strategies. Health Technol Assess Winch Engl 2004;8:iii-iv, 1-72.

[25] World economic situation and prosepcts. New York: United Nations Publication; 2018.

[26] Prevention and Management of Postpartum Haemorrhage: Green-top Guideline No. 52. BJOG Int J Obstet Gynaecol 2017;124:e106-49. doi:10.1111/1471-0528.14178.

[27] Althabe F, Buekens P, Bergel E, Belizán JM, Campbell MK, Moss N, et al. A behavioral intervention to improve obstetrical care. N Engl J Med 2008;358:1929-40. doi:10.1056/NEJMsa071456.

[28] Shields LE, Wiesner S, Fulton J, Pelletreau B. Comprehensive maternal hemorrhage protocols reduce the use of blood products and improve patient safety. Am J Obstet Gynecol 2015;212:272-80. doi:10.1016/j.ajog.2014.07.012.

[29] Markova V, Sørensen JL, Holm C, Nørgaard A, Langhoff-Roos J. Evaluation of multi-professional obstetric skills training for postpartum hemorrhage. Acta Obstet Gynecol Scand 2012;91:34652. doi:10.1111/j.1600-0412.2011.01344.x.

[30] Egenberg S, Masenga G, Bru LE, Eggeb $\varnothing$ TM, Mushi C, Massay D, et al. Impact of multiprofessional, scenario-based training on postpartum hemorrhage in Tanzania: a quasiexperimental, pre- vs. post-intervention study. BMC Pregnancy Childbirth 2017;17:287. doi:10.1186/s12884-017-1478-2.

[31] Fransen AF, van de Ven J, Schuit E, van Tetering A, Mol BW, Oei SG. Simulation-based team training for multi-professional obstetric care teams to improve patient outcome: a multicentre, cluster randomised controlled trial. BJOG Int J Obstet Gynaecol 2017;124:641-50. doi:10.1111/1471-0528.14369.

[32] Dumont A, Fournier P, Abrahamowicz M, Traoré M, Haddad S, Fraser WD, et al. Quality of care, risk management, and technology in obstetrics to reduce hospital-based maternal mortality in Senegal and Mali (QUARITE): a cluster-randomised trial. Lancet Lond Engl 2013;382:146-57. doi:10.1016/S0140-6736(13)60593-0.

[33] Deneux-Tharaux C, Dupont C, Colin C, Rabilloud M, Touzet S, Lansac J, et al. Multifaceted intervention to decrease the rate of severe postpartum haemorrhage: the PITHAGORE6 clusterrandomised controlled trial. BJOG Int J Obstet Gynaecol 2010;117:1278-87. doi:10.1111/j.1471-0528.2010.02648.x. 
[34] Walker DM, Cohen SR, Fritz J, Olvera-García M, Zelek ST, Fahey JO, et al. Impact Evaluation of PRONTO Mexico: A Simulation-Based Program in Obstetric and Neonatal Emergencies and Team Training. Simul Healthc J Soc Simul Healthc 2016;11:1-9. doi:10.1097/SIH.0000000000000106.

[35] Egenberg S, Øian P, Eggeb $\varnothing$ TM, Arsenovic MG, Bru LE. Changes in self-efficacy, collective efficacy and patient outcome following interprofessional simulation training on postpartum haemorrhage. J Clin Nurs 2017;26:3174-87. doi:10.1111/jocn.13666.

[36] Ellard DR, Shemdoe A, Mazuguni F, Mbaruku G, Davies D, Kihaile P, et al. Can training nonphysician clinicians/associate clinicians (NPCs/ACs) in emergency obstetric, neonatal care and clinical leadership make a difference to practice and help towards reductions in maternal and neonatal mortality in rural Tanzania? The ETATMBA project. BMJ Open 2016;6:e008999. doi:10.1136/bmjopen-2015-008999.

[37] Shoushtarian M, Barnett M, McMahon F, Ferris J. Impact of introducing practical obstetric multi-professional training (PROMPT) into maternity units in Victoria, Australia. BJOG Int J Obstet Gynaecol 2014;121:1710-8. doi:10.1111/1471-0528.12767.

[38] Egenberg S, Øian P, Bru LE, Sautter M, Kristoffersen G, Eggeb $\varnothing$ TM. Can inter-professional simulation training influence the frequency of blood transfusions after birth? Acta Obstet Gynecol Scand 2015;94:316-23. doi:10.1111/aogs.12569.

[39] Dupont C, Occelli P, Deneux-Tharaux C, Touzet S, Duclos A, Bouvier-Colle M-H, et al. Severe postpartum haemorrhage after vaginal delivery: a statistical process control chart to report seven years of continuous quality improvement. Eur J Obstet Gynecol Reprod Biol 2014;178:169-75. doi:10.1016/j.ejogrb.2014.04.021.

[40] Dupont C, Deneux-Tharaux C, Touzet S, Colin C, Bouvier-Colle M-H, Lansac J, et al. Clinical audit: a useful tool for reducing severe postpartum haemorrhages? Int J Qual Health Care J Int Soc Qual Health Care ISQua 2011;23:583-9. doi:10.1093/intqhc/mzr042.

[41] Shields LE, Smalarz K, Reffigee L, Mugg S, Burdumy TJ, Propst M. Comprehensive maternal hemorrhage protocols improve patient safety and reduce utilization of blood products. Am J Obstet Gynecol 2011;205:368.e1-8. doi:10.1016/j.ajog.2011.06.084.

[42] Audureau E, Deneux-Tharaux C, Lefèvre P, Brucato S, Morello R, Dreyfus M, et al. Practices for prevention, diagnosis and management of postpartum haemorrhage: impact of a regional multifaceted intervention. BJOG Int J Obstet Gynaecol 2009;116:1325-33. doi:10.1111/j.14710528.2009.02238.x.

[43] Liabsuetrakul Tippawan, Palanukunwong Kanokporn, Chinduereh Anan, Oumudee Nurlisa. Evaluation of a multifaceted postpartum hemorrhage-management intervention in community hospitals in Southern Thailand. Int J Gynecol Obstet 2017;139:39-44. doi:10.1002/ijgo.12253.

[44] Shields LE, Wiesner S, Klein C, Pelletreau B, Hedriana HL. Use of Maternal Early Warning Trigger tool reduces maternal morbidity. Am J Obstet Gynecol 2016;214:527.e1-527.e6. doi:10.1016/j.ajog.2016.01.154.

[45] Sorensen BL, Rasch V, Massawe S, Nyakina J, Elsass P, Nielsen BB. Advanced life support in obstetrics (ALSO) and post-partum hemorrhage: a prospective intervention study in Tanzania. Acta Obstet Gynecol Scand 2011;90:609-14. doi:10.1111/j.1600-0412.2011.01115.x.

[46] Nelissen E, Ersdal H, Mduma E, Evjen-Olsen B, Twisk J, Broerse J, et al. Clinical performance and patient outcome after simulation-based training in prevention and management of postpartum haemorrhage: an educational intervention study in a low-resource setting. BMC Pregnancy Childbirth 2017;17:301. doi:10.1186/s12884-017-1481-7.

[47] Kumar A, Sturrock S, Wallace EM, Nestel D, Lucey D, Stoyles S, et al. Evaluation of learning from Practical Obstetric Multi-Professional Training and its impact on patient outcomes in Australia using Kirkpatrick's framework: a mixed methods study. BMJ Open 2018;8:e017451. doi:10.1136/bmjopen-2017-017451.

[48] Shields LE, Smalarz K, Reffigee L, Mugg S, Burdumy TJ, Propst M. Comprehensive maternal hemorrhage protocols improve patient safety and reduce utilization of blood products. Am J Obstet Gynecol 2011;205:368.e1-8. doi:10.1016/j.ajog.2011.06.084. 
[49] Rizvi F, Mackey R, Barrett T, McKenna P, Geary M. Successful reduction of massive postpartum haemorrhage by use of guidelines and staff education. BJOG Int J Obstet Gynaecol 2004;111:495-8. doi:10.1111/j.1471-0528.2004.00103.x.

[50] Figueras A, Narváez E, Valsecia M, Vásquez S, Rojas G, Camilo A, et al. An education and motivation intervention to change clinical management of the third stage of labor - the GIRMMAHP Initiative. Birth Berkeley Calif 2008;35:283-90. doi:10.1111/j.1523536X.2008.00255.x.

[51] Berg CJ, Harper MA, Atkinson SM, Bell EA, Brown HL, Hage ML, et al. Preventability of pregnancy-related deaths: results of a state-wide review. Obstet Gynecol 2005;106:1228-34. doi:10.1097/01.AOG.0000187894.71913.e8.

[52] Chaillet N, Dubé E, Dugas M, Audibert F, Tourigny C, Fraser WD, et al. Evidence-based strategies for implementing guidelines in obstetrics: a systematic review. Obstet Gynecol 2006;108:123445. doi:10.1097/01.AOG.0000236434.74160.8b.

[53] Campbell M, Fitzpatrick R, Haines A, Kinmonth AL, Sandercock P, Spiegelhalter D, et al. Framework for design and evaluation of complex interventions to improve health. BMJ 2000;321:694-6.

[54] Craig P, Dieppe P, Macintyre S, Michie S, Nazareth I, Petticrew M, et al. Developing and evaluating complex interventions: the new Medical Research Council guidance. BMJ 2008;337:a1655.

[55] Craig P, Dieppe P, Macintyre S, Michie S, Nazareth I, Petticrew M. Developing and evaluating complex interventions: new guidance 2008.

[56] Meher S, Cuthbert A, Kirkham J, Williamson P, Abalos E, Aflaifel N, et al. Core outcome sets for prevention and treatment of postpartum haemorrhage: an international Delphi consensus study. BJOG Int J Obstet Gynaecol 2018;0. doi:10.1111/1471-0528.15335.

[57] Diaz V, Abalos E, Carroli G. Methods for blood loss estimation after vaginal birth. Cochrane Database Syst Rev 2018;9:CD010980. doi:10.1002/14651858.CD010980.pub2.

[58] Skupski DW, Lowenwirt IP, Weinbaum FI, Brodsky D, Danek M, Eglinton GS. Improving hospital systems for the care of women with major obstetric hemorrhage. Obstet Gynecol 2006;107:977-83. doi:10.1097/01.AOG.0000215561.68257.c5.

[59] Einerson BD, Miller ES, Grobman WA. Does a postpartum hemorrhage patient safety program result in sustained changes in management and outcomes? Am J Obstet Gynecol 2015;212:140144.e1. doi:10.1016/j.ajog.2014.07.004.

[60] Allgöwer M, Burri C. „Schockindex”. DMW - Dtsch Med Wochenschr 1967;92:1947-50. doi:10.1055/s-0028-1106070.

[61] Borovac-Pinheiro A, Pacagnella RC, Cecatti JG, Miller S, El Ayadi AM, Souza JP, et al. Postpartum hemorrhage: new insights for definition and diagnosis. Am J Obstet Gynecol 2018;219:162-8. doi:10.1016/j.ajog.2018.04.013.

[62] Möhler R, Bartoszek G, Meyer G. Quality of reporting of complex healthcare interventions and applicability of the CReDECI list - a survey of publications indexed in PubMed. BMC Med Res Methodol 2013;13:125. doi:10.1186/1471-2288-13-125.

[63] Möhler R, Köpke S, Meyer G. Criteria for Reporting the Development and Evaluation of Complex Interventions in healthcare: revised guideline (CReDECI 2). Trials 2015;16:204. doi:10.1186/s13063-015-0709-y.

[64] Lee Al, Wong CA, Healy L, Toledo P. Impact of a third stage of labor oxytocin protocol on cesarean delivery outcomes. Int J Obstet Anesth 2014;23:18-22. doi:10.1016/j.ijoa.2013.09.004.

[65] Dagraca J, Malladi V, Nunes K, Scavone B. Outcomes after institution of a new oxytocin infusion protocol during the third stage of labor and immediate postpartum period. Int J Obstet Anesth 2013;22:194-9. doi:10.1016/j.ijoa.2013.03.007.

[66] Baldvinsdóttir T, Blomberg M, Lilliecreutz C. Improved clinical management but not patient outcome in women with postpartum haemorrhage-An observational study of practical obstetric team training. PloS One 2018;13:e0203806. doi:10.1371/journal.pone.0203806. 
[67] Hamm R, Wang E, O'Rourke K, Romanos A, Srinivas S. Institution of a Comprehensive Postpartum Hemorrhage Bundle at a Large Academic Center does not Immediately Reduce Maternal Morbidity. Am J Perinatol 2018. doi:10.1055/s-0038-1629910.

[68] Nadisauskiene RJ, Dobozinskas P, Kacerauskiene J, Kliucinskas M, Zhumagali I, Kokenova M, et al. The impact of the implementation of the postpartum haemorrhage management guidelines at the first regional perinatal centre in Southern Kazakhstan. BMC Pregnancy Childbirth 2016;16:238. doi:10.1186/s12884-016-1027-4.

[69] Lappen JR, Seidman D, Burke C, Goetz K, Grobman WA. Changes in care associated with the introduction of a postpartum hemorrhage patient safety program. Am J Perinatol 2013;30:8338. doi:10.1055/s-0033-1333674.

[70] Ducloy-Bouthors A-S, Ducloy J-C, Sicot J. Impact of a perinatal network medical practice improvement program on postpartum hemorrhage-related morbidity. Int J Gynecol Obstet 2008;104:68-9. doi:10.1016/j.ijgo.2008.08.022. 


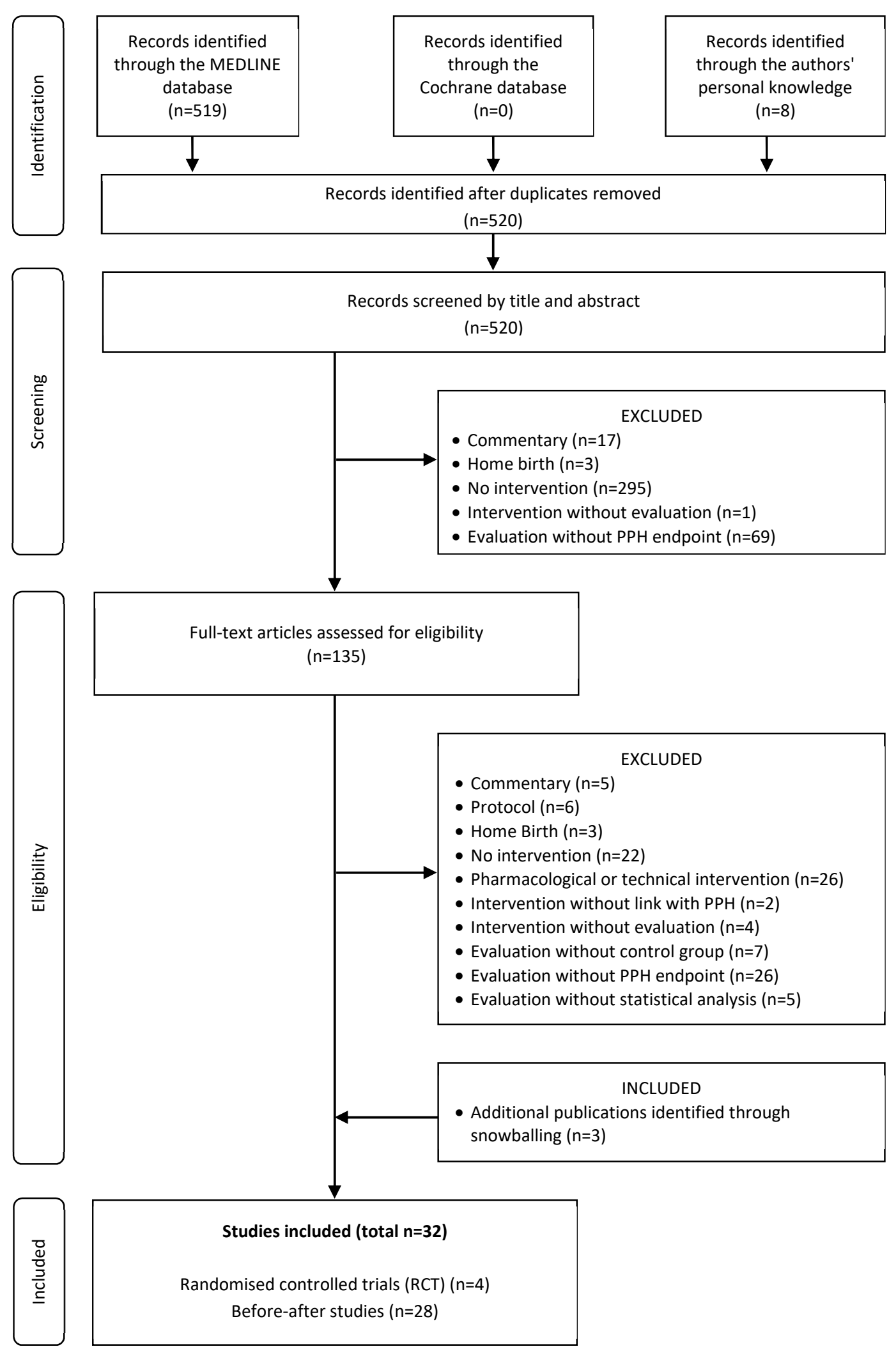

Figure 1 - Flow chart of the systematic review 
Table 1 - Cochrane EPOC methodological quality criteria

\begin{tabular}{|c|c|c|c|c|c|c|c|}
\hline Randomised Control Trials & 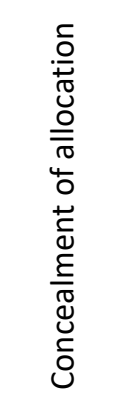 & 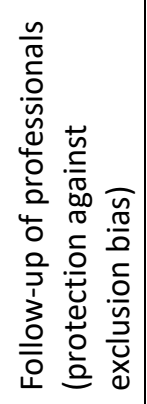 & 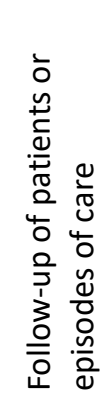 & 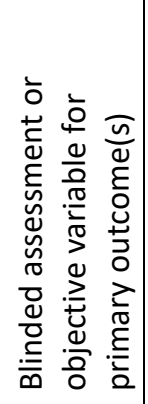 & 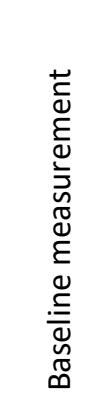 & 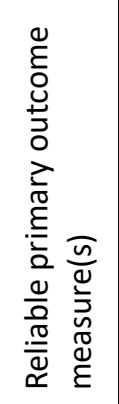 & 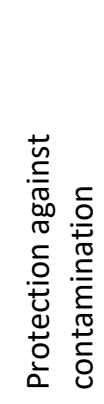 \\
\hline Althabe et al, 2008 [27] & DONE & DONE & DONE & NA & DONE & DONE & DONE \\
\hline Walker et al, 2016 [34] & NC & ND & DONE & NA & DONE & DONE & ND \\
\hline Dumont et al, 2013 [32] & DONE & DONE & DONE & NA & DONE & DONE & NC \\
\hline Deneux-Tharaux et al 2010 [33] & DONE & DONE & DONE & DONE & ND & NC & ND \\
\hline
\end{tabular}

\begin{tabular}{|c|c|c|c|c|c|c|c|}
\hline Before-After Studies & 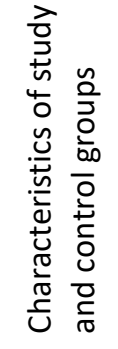 & 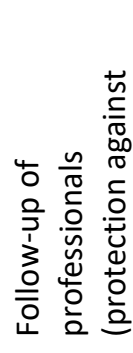 & 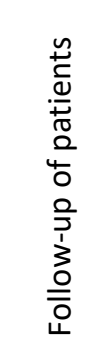 & 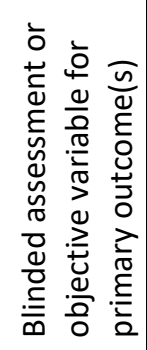 & 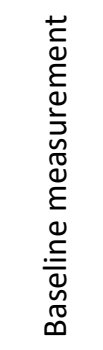 & 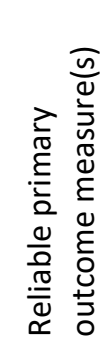 & 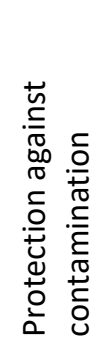 \\
\hline Lee et al. 2014 [64] & DONE & NC & DONE & NA & DONE & ND & DONE \\
\hline Da Graca et al. 2013 [65] & DONE & NC & DONE & NC & DONE & ND & DONE \\
\hline Rizvi et al. 2004 [49] & DONE & DONE & DONE & NC & DONE & ND & DONE \\
\hline Baldvinsdottir T et al. 2018 [66] & ND & DONE & DONE & ND & DONE & ND & DONE \\
\hline Kumar A et al. 2018 [47] & ND & DONE & DONE & ND & DONE & NC & DONE \\
\hline Egenberg S et al. Oct. 2017 [35] & DONE & ND & DONE & NA & DONE & DONE & DONE \\
\hline Egenberg S et al. Sept. 2017 [30] & ND & DONE & DONE & DONE & DONE & DONE & DONE \\
\hline Liabsuetrakul T et al. 2017 [43] & DONE & NC & DONE & NC & DONE & ND & NC \\
\hline Fransen A et al. 2016 [31] & DONE & DONE & DONE & DONE & DONE & DONE & DONE \\
\hline Shields LE et al. 2016 [44] & ND & NA & DONE & NC & DONE & NC & DONE \\
\hline Ellard DR et al. 2016 [36] & ND & NC & DONE & NC & DONE & NC & DONE \\
\hline Shoushtarian M et al. 2014 [37] & ND & ND & DONE & NA & DONE & NC & DONE \\
\hline Skupski DW et al. 2006 [58] & DONE & DONE & DONE & NC & DONE & ND & DONE \\
\hline Hamm RF et al. 2018 [67] & DONE & DONE & DONE & NC & DONE & DONE & DONE \\
\hline Nelissen E et al. 2017 [46] & DONE & NC & DONE & NC & DONE & ND & DONE \\
\hline Nadisauskiene RJ et al. 2016 [68] & DONE & NC & DONE & NC & DONE & ND & DONE \\
\hline Einerson BD et al. 2015 [59] & DONE & DO & DONE & NA & DONE & NC & DONE \\
\hline Egenberg S et al. 2015 [38] & ND & NC & DONE & NA & DONE & ND & DONE \\
\hline Shields LE et al. 2015 [28] & ND & NC & DONE & DONE & DONE & DONE & DONE \\
\hline Dupont C et al. 2014 [39] & ND & DONE & DONE & NC & ND & DONE & DONE \\
\hline Lappen JR et al. 2013 [69] & DONE & DONE & DONE & NC & DONE & NC & DONE \\
\hline Markova V et al. 2012 [29] & ND & DONE & DONE & DONE & ND & DONE & DONE \\
\hline Sorensen BL et al. 2011 [45] & DONE & NC & DONE & NC & DONE & DONE & DONE \\
\hline Dupont C et al. 2011 [40] & ND & DONE & DONE & NC & ND & DONE & DONE \\
\hline Shields LE et al. 2011 [41] & ND & NC & DONE & NC & DONE & ND & DONE \\
\hline Audureau E et al. 2009 [42] & ND & DONE & DONE & NA & DONE & DONE & DONE \\
\hline Figueras A et al. 2008 [50] & DONE & DONE & DONE & NA & DONE & NC & DONE \\
\hline Ducloy-Bouthors AS el al. 2008 [70 & ND & NC & NC & NC & DONE & NC & DONE \\
\hline
\end{tabular}

NC, not clear; ND, not done; NA, not applicable.

When the primary outcome of the study did not concern minor or major PPH rates directly, the methodological quality criterion regarding the objectivity of the primary outcome was considered not applicable. 
Table 2 - Report of the efficacy according to intervention type and study design

\begin{tabular}{|c|c|c|c|c|c|}
\hline $\begin{array}{l}\text { Author. Year of } \\
\text { publication. } \\
\text { Country (Economic } \\
\text { development level). }\end{array}$ & $\begin{array}{l}\text { Number of } \\
\text { women (mode of } \\
\text { delivery). } \\
\text { Number of units; } \\
\text { Year of } \\
\text { intervention. }\end{array}$ & $\begin{array}{l}\text { Intervention. } \\
\text { Study design. }\end{array}$ & $\begin{array}{l}\text { Definition of PPH as outcome. } \\
\text { Method of estimation of blood loss. }\end{array}$ & $\begin{array}{lrll}\text { PPH rates } & \text { before } & \text { vs. } & \text { after } \\
\text { intervention } & & & \end{array}$ & $\begin{array}{l}P \text { - } \\
\text { value }\end{array}$ \\
\hline $\begin{array}{l}\text { Lee Al et al. } 2014 \text { [64]. } \\
\text { USA (Dped). }\end{array}$ & $\begin{array}{l}901 \text { (CS). } \\
1 \text { unit; } 2008 .\end{array}$ & $\begin{array}{l}\text { Guideline } \\
\text { dissemination. } \\
\text { Before-after study. }\end{array}$ & $\begin{array}{l}\text { Blood loss }>1000 \mathrm{ml} \text {. } \\
\text { Visual estimation. }\end{array}$ & $21 \%$ vs. $24 \%$ & NS \\
\hline $\begin{array}{l}\text { Da Graca J et al. } 2013 \\
\text { [65]. } \\
\text { USA (Dped). }\end{array}$ & $\begin{array}{l}1572 \text { (VD and CS). } \\
1 \text { unit; } 2011 .\end{array}$ & $\begin{array}{l}\text { Guideline } \\
\text { dissemination. } \\
\text { Before-after study. }\end{array}$ & $\begin{array}{l}\text { Blood loss }>500 \mathrm{ml} \text { for VD and }>1000 \\
\mathrm{ml} \text { for CS. } \\
\text { Visual estimation or weighing. }\end{array}$ & $9.0 \%$ vs. $7.1 \%$ & NS \\
\hline $\begin{array}{l}\text { Althabe } F \text { et al. } 2008 \\
\text { [27]. } \\
\text { Argentina, } \\
\text { (Dping). }\end{array}$ & $\begin{array}{l}10419 \text { (VD). } \\
19 \text { units; 2003- } \\
2015 .\end{array}$ & $\begin{array}{l}\text { Multifaceted } \\
\text { intervention. } \\
\text { RCT. }\end{array}$ & $\begin{array}{l}\text { Minor PPH for blood loss } \geq 500 \mathrm{ml} \\
\text { and major PPH for blood loss } \geq 1000 \\
\mathrm{ml} \text {. } \\
\text { Not detailed. }\end{array}$ & $\begin{array}{l}\text { Minor PPH: } \\
\text { - Control group: } 18.6 \% \text { vs. } 6.9 \% \\
\text { - Intervention group: } 9.8 \% \text { vs. } 8.1 \% \\
\text { Major PPH: } \\
\text { - Control group: } 3.0 \% \text { vs. } 0.8 \% \\
\text { - Intervention group: } 1.5 \% \text { vs. } 0.6 \%\end{array}$ & 0.03 \\
\hline $\begin{array}{l}\text { Rizvi F et al. } 2004 \text { [49]. } \\
\text { Ireland (Dped). }\end{array}$ & $\begin{array}{l}6476 \text { (VD and CS). } \\
1 \text { unit; } 1999-2002 .\end{array}$ & $\begin{array}{l}\text { Multifaceted } \\
\text { intervention. } \\
\text { Before-after study. }\end{array}$ & $\begin{array}{l}\text { Blood loss }>1000 \mathrm{ml} \text {. } \\
\text { Visual estimation or weighing. }\end{array}$ & $1.7 \%$ vs. $0.45 \%$ & 0.01 \\
\hline $\begin{array}{l}\text { Baldvinsdottir T et al. } \\
2018 \text { [66]. } \\
\text { Sweden (Dped). }\end{array}$ & $\begin{array}{l}902 \text { (VD). } \\
1 \text { unit, } 2008 .\end{array}$ & $\begin{array}{l}\text { In-centre simulation. } \\
\text { Before-after study. }\end{array}$ & $\begin{array}{l}\text { Blood loss } \geq 1000 \mathrm{ml} \text {. } \\
\text { Visual estimation then weighing. }\end{array}$ & $1632.5 \mathrm{ml}$ vs. $1738.6 \mathrm{ml}$ & 0.03 \\
\hline $\begin{array}{l}\text { Kumar A et al. } 2018 \text { [47]. } \\
\text { Austria (Dped). }\end{array}$ & $\begin{array}{l}27749 \text { (VD and } \\
\text { CS). } \\
3 \text { units; 2011- } \\
2015 .\end{array}$ & $\begin{array}{l}\text { Training. } \\
\text { Before-after study. }\end{array}$ & $\begin{array}{l}\text { Blood loss between } 1000 \text { and } \\
1499 \mathrm{ml} \\
\text { Not detailed. }\end{array}$ & $3.7 \%$ vs. $4.1 \%$ & NS \\
\hline
\end{tabular}




\begin{tabular}{|c|c|c|c|c|c|}
\hline $\begin{array}{l}\text { Egenberg } S \text { et al. Oct. } \\
2017 \text { [35]. } \\
\text { Norway (Dped). }\end{array}$ & $\begin{array}{l}5446 \text { (VD and CS). } \\
1 \text { unit; } 2015 .\end{array}$ & $\begin{array}{l}\text { On-site simulation. } \\
\text { Before-after study. }\end{array}$ & $\begin{array}{l}\text { Simple PPH for blood transfusion } \geq 1 \\
\text { unit; severe PPH for massive } \\
\text { transfusion. } \\
\text { Not detailed. }\end{array}$ & $\begin{array}{l}\text { Simple PPH: } 5 \% \text { vs. } 4 \% \\
\text { Severe PPH: } 14 \% \text { vs. } 6 \%\end{array}$ & $\begin{array}{l}\text { NS } \\
0.04\end{array}$ \\
\hline $\begin{array}{l}\text { Egenberg S et al. Sept. } \\
2017 \text { [30]. } \\
\text { Tanzania (Dping). }\end{array}$ & $\begin{array}{l}3308 \text { (VD and CS). } \\
1 \text { unit; 2012-2014. }\end{array}$ & $\begin{array}{l}\text { On-site simulation. } \\
\text { Before-after study. }\end{array}$ & $\begin{array}{l}\text { Blood transfusion for } \mathrm{PPH} \\
\text { management. } \\
\text { Visual estimation. }\end{array}$ & $3.2 \%$ vs. $1.7 \%$ & $<0.01$ \\
\hline $\begin{array}{l}\text { Liabsuetrakul T et al. } \\
2017 \text { [43]. } \\
\text { Thailand (Dping). }\end{array}$ & $\begin{array}{l}9459 \text { (VD and CS). } \\
6 \text { units; 2011- } \\
2014 .\end{array}$ & $\begin{array}{l}\text { Multifaceted } \\
\text { intervention. } \\
\text { Controlled before-after } \\
\text { study. }\end{array}$ & $\begin{array}{l}\text { PPH mentioned in clinical records. } \\
\text { Visual estimation. }\end{array}$ & $\begin{array}{l}\text { Control group: } 1.4 \% \text { vs. } 1.7 \% \\
\text { Intervention group: } 1.7 \% \text { vs. } 2.0 \%\end{array}$ & NS \\
\hline $\begin{array}{l}\text { Fransen A et al. } 2016 \\
\text { [31]. } \\
\text { Netherlands (Dped). }\end{array}$ & $\begin{array}{l}56166 \text { (VD and } \\
\text { CS). } \\
24 \text { units; 2009- } \\
2011 .\end{array}$ & $\begin{array}{l}\text { On-site simulation. } \\
\text { Controlled before-after } \\
\text { study. }\end{array}$ & $\begin{array}{l}\text { Severe PPH management. } \\
\text { Administration of }>4 \text { packed cells } \\
\text { blood transfusion, or the } \\
\text { performance of an embolization or } \\
\text { hysterectomy. }\end{array}$ & $0.14 \%$ vs. $0.28 \%$ & 0.009 \\
\hline $\begin{array}{l}\text { Shields LE et al. } 2016 \\
\text { [44]. } \\
\text { USA (Dped). }\end{array}$ & $\begin{array}{l}63252 \text { (VD and } \\
\text { CS). } \\
29 \text { units; 2012- } \\
2015 \text {. }\end{array}$ & $\begin{array}{l}\text { Pathway. } \\
\text { Controlled before-after } \\
\text { study. }\end{array}$ & $\begin{array}{l}\text { Blood loss }>500 \mathrm{ml} \text { for VD and }>1000 \\
\mathrm{ml} \text { for CS. } \\
\text { Not detailed. }\end{array}$ & $2.9 \%$ vs. $2.7 \%$ & NS \\
\hline $\begin{array}{l}\text { Walker DM et al. } 2016 \\
\text { [34]. } \\
\text { Mexico (Dping). }\end{array}$ & $\begin{array}{l}50589 \text { (VD and } \\
\text { CS). } \\
24 \text { units; 2010- } \\
2013 \text {. }\end{array}$ & $\begin{array}{l}\text { In-centre simulation. } \\
\text { Pair-matched RCT. }\end{array}$ & $\begin{array}{l}\text { Not detailed. } \\
\text { Not detailed. }\end{array}$ & $\begin{array}{l}\text { Incidence rate ratio at } 4,8 \text { and } 12 \\
\text { months: } 0.58 / 0.88 / 0.60\end{array}$ & NS \\
\hline $\begin{array}{l}\text { Ellard DR et al. } 2016 \\
\text { [36]. } \\
\text { Tanzania (Dping). }\end{array}$ & $\begin{array}{l}49834 \text { (VD and } \\
\text { CS) } \\
16 \text { units; 2011, } \\
2013 .\end{array}$ & $\begin{array}{l}\text { Training. } \\
\text { Before-after study. }\end{array}$ & $\begin{array}{l}\text { PPH mentioned in clinical records. } \\
\text { Not detailed. }\end{array}$ & $11.0 \%$ vs. $12.6 \%$ & NS \\
\hline $\begin{array}{l}\text { Shoushtarian M et al. } \\
2014 \text { [37]. } \\
\text { Australia (Dped). }\end{array}$ & $\begin{array}{l}43408 \text { (VD and } \\
\text { CS). } \\
8 \text { units; 2008- } \\
2011 .\end{array}$ & $\begin{array}{l}\text { In-centre simulation. } \\
\text { Before-after study. }\end{array}$ & $\begin{array}{l}\text { Blood loss }>1500 \mathrm{ml} \\
\text { Not detailed. }\end{array}$ & $1.2 \%$ vs. $1.3 \%$ & NS \\
\hline
\end{tabular}




\begin{tabular}{|c|c|c|c|c|c|}
\hline $\begin{array}{l}\text { Skupski DW et al. } 2006 \\
\text { [58]. } \\
\text { USA (Dped). }\end{array}$ & $\begin{array}{l}18723 \text { (VD and } \\
\text { CS) } \\
1 \text { unit; } 2000-2005 .\end{array}$ & $\begin{array}{l}\text { Multifaceted } \\
\text { intervention. } \\
\text { Before-after study. }\end{array}$ & $\begin{array}{l}\text { Blood loss } \geq 1500 \mathrm{ml} \text { or } \mathrm{PPH} \\
\text { management. } \\
\text { Not detailed. }\end{array}$ & $0.2 \%$ vs. $0.4 \%$ & 0.02 \\
\hline $\begin{array}{l}\text { Hamm RF et al. } 2018 \\
\text { [67]. } \\
\text { USA (Dped). }\end{array}$ & $\begin{array}{l}1175 \text { (VD and CS). } \\
1 \text { unit; 2013-2015. }\end{array}$ & $\begin{array}{l}\text { Multifaceted } \\
\text { intervention. } \\
\text { Before-after study. }\end{array}$ & $\begin{array}{l}\text { Blood loss } \geq 1000 \mathrm{ml} \\
\text { Visual estimation. }\end{array}$ & $9.0 \%$ vs. $12.2 \%$ & NS \\
\hline $\begin{array}{l}\text { Nelissen E et al. } 2017 \\
\text { [46]. } \\
\text { Tanzania (Dping). }\end{array}$ & $\begin{array}{l}9446 \text { (VD and CS). } \\
1 \text { unit; 2011-2013. }\end{array}$ & $\begin{array}{l}\text { On-site simulation. } \\
\text { Before-after study. }\end{array}$ & $\begin{array}{l}\text { Blood loss } \geq 500 \mathrm{ml} \\
\text { Visual estimation. }\end{array}$ & $2.1 \%$ vs. $1.3 \%$ & 0.003 \\
\hline $\begin{array}{l}\text { Nadisauskiene RJ et al. } \\
2016 \text { [68]. } \\
\text { Kazakhstan (trans). }\end{array}$ & $\begin{array}{l}11360 \text { (VD and } \\
\text { CS). } \\
1 \text { unit; } 2012-2013 .\end{array}$ & $\begin{array}{l}\text { Multifaceted } \\
\text { intervention. } \\
\text { Before-after study. }\end{array}$ & $\begin{array}{l}\text { Simple PPH: blood loss } \geq 500 \mathrm{ml} \text { for } \\
\text { VD or } \geq 1000 \mathrm{ml} \text { for } \mathrm{CS} \text {; severe } \mathrm{PPH} \text { : } \\
\text { blood loss } \geq 1500 \mathrm{ml} \text {. } \\
\text { Visual estimation. }\end{array}$ & $\begin{array}{l}\text { Simple PPH: } 1.17 \% \text { vs. } 1.02 \% \\
\text { Severe PPH: } 0.24 \% \text { vs. } 0.22 \%\end{array}$ & $\begin{array}{l}\text { NS } \\
\text { NS }\end{array}$ \\
\hline $\begin{array}{l}\text { Einerson BD et al. } 2015 \\
\text { [59]. } \\
\text { USA (Dped). }\end{array}$ & $\begin{array}{l}3105 \text { (VD and CS). } \\
1 \text { unit; 2007-2011. }\end{array}$ & $\begin{array}{l}\text { Multifaceted } \\
\text { intervention. } \\
\text { Before-after study. }\end{array}$ & $\begin{array}{l}\text { Simple PPH: blood loss }>500 \mathrm{ml} \text { for } \\
\text { VD or }>1000 \mathrm{ml} \text { for CS; severe } \mathrm{PPH} \text { : } \\
\text { blood loss }>1500 \mathrm{ml} \text {. } \\
\text { Not detailed. }\end{array}$ & $\begin{array}{l}\text { Simple PPH: } 5.3 \% \text { vs. } 6.0 \% \\
\text { Severe PPH: } 21.5 \% \text { vs. } 26.6 \%\end{array}$ & $\begin{array}{l}0.02 \\
0.001\end{array}$ \\
\hline $\begin{array}{l}\text { Egenberg S et al. } 2015 \\
\text { [38]. } \\
\text { Norway (Dped). }\end{array}$ & $\begin{array}{l}1080 \text { (VD and CS) } \\
1 \text { unit; 2009, } \\
2011 .\end{array}$ & $\begin{array}{l}\text { In-centre simulation. } \\
\text { Before-after study. }\end{array}$ & $\begin{array}{l}\text { Blood loss }>500 \mathrm{ml} \\
\text { Visual estimation. }\end{array}$ & $11.2 \%$ vs. $11.2 \%$ & NS \\
\hline $\begin{array}{l}\text { Shields LE et al. } 2015 \\
\text { [28]. } \\
\text { USA (Dped). }\end{array}$ & $\begin{array}{l}32059 \text { (VD and } \\
\text { CS). } \\
29 \text { units; } 2011 .\end{array}$ & $\begin{array}{l}\text { Audit and feedback. } \\
\text { Before-after study. }\end{array}$ & $\begin{array}{l}\text { Blood transfusion for PPH } \\
\text { management. } \\
\text { Visual estimation or weighing. }\end{array}$ & $35.9 \%$ vs. $26.6 \%$ & $<0.01$ \\
\hline $\begin{array}{l}\text { Dupont C et al. } 2014 \\
\text { [39]. } \\
\text { France (Dped). }\end{array}$ & $\begin{array}{l}21822 \text { (VD). } \\
1 \text { unit; 2005-2012. }\end{array}$ & $\begin{array}{l}\text { Audit and feedback. } \\
\text { Before-after study. }\end{array}$ & $\begin{array}{l}\text { Blood loss }>1500 \mathrm{ml} \text { or intensive } \\
\text { management. } \\
\text { Measured with a collector bag. }\end{array}$ & $1.2 \%$ vs. $0.6 \%$ & $<0.001$ \\
\hline $\begin{array}{l}\text { Dumont A et al. } 2013 \\
\text { [32]. } \\
\text { Senegal \& Mali (Dping). }\end{array}$ & $\begin{array}{l}197306 \text { (VD and } \\
\text { CS) } \\
46 \text { units; } 2008 .\end{array}$ & $\begin{array}{l}\text { Multifaceted } \\
\text { intervention. } \\
\text { RCT. }\end{array}$ & $\begin{array}{l}\text { Blood transfusion for PPH } \\
\text { management. } \\
\text { Not detailed. }\end{array}$ & $\begin{array}{l}\text { Control group: } 44.5 \% \text { to } 51.9 \% \\
\text { Intervention group: } 43.4 \% \text { vs. } 45.7 \%\end{array}$ & 0.002 \\
\hline $\begin{array}{l}\text { Lappen JR et al. } 2013 \\
\text { [69]. } \\
\text { USA (Dped). }\end{array}$ & $\begin{array}{l}419 \text { (VD and CS) } \\
1 \text { unit; 2008-2009. }\end{array}$ & $\begin{array}{l}\text { Multifaceted } \\
\text { intervention. } \\
\text { Before-after study. }\end{array}$ & $\begin{array}{l}\text { Blood loss }>500 \mathrm{ml} \text { for } \mathrm{VD} \text { or }>1000 \\
\mathrm{ml} \text { for CS. } \\
\text { Not detailed. }\end{array}$ & $4.8 \%$ vs. $5.1 \%$ & NS \\
\hline
\end{tabular}




\begin{tabular}{|c|c|c|c|c|c|}
\hline $\begin{array}{l}\text { Markova V et al. } 2012 \\
\text { [29]. } \\
\text { Denmark (Dped). }\end{array}$ & $\begin{array}{l}10461 \text { (VD and } \\
\text { CS). } \\
1 \text { unit; 2003-2007. }\end{array}$ & $\begin{array}{l}\text { On-site simulation. } \\
\text { Before-after study. }\end{array}$ & $\begin{array}{l}\text { Blood transfusion for } \mathrm{PPH} \\
\text { management. } \\
\text { Not detailed. }\end{array}$ & $\begin{array}{l}\text { Incidence rate ratio in } 2003,2005 \text { and } \\
2007: 1.5 \% / 1.6 \% / 1.2 \%\end{array}$ & NS \\
\hline $\begin{array}{l}\text { Sorensen BL et al. } 2011 \\
\text { [45]. } \\
\text { Tanzania (Dping). }\end{array}$ & $\begin{array}{l}505 \text { (VD). } \\
1 \text { unit; } 2008 .\end{array}$ & $\begin{array}{l}\text { Training. } \\
\text { Before-after study. }\end{array}$ & $\begin{array}{l}\text { Minor PPH: blood loss } \geq 500 \mathrm{ml} \text {; } \\
\text { major PPH: blood loss } \geq 1000 \mathrm{ml} \text {. } \\
\text { Weighing. }\end{array}$ & $\begin{array}{l}\text { Minor PPH: } 32.9 \% \text { vs. } 18.2 \% \\
\text { Major PPH: } 9.2 \% \text { vs. } 4.3 \%\end{array}$ & $\begin{array}{l}<0.05 \\
<0.05\end{array}$ \\
\hline $\begin{array}{l}\text { Dupont C et al. } 2011 \\
\text { [40]. } \\
\text { France (Dped). }\end{array}$ & $\begin{array}{l}18804 \text { (VD and } \\
\text { CS). } \\
2 \text { units; 2005- } \\
2008 .\end{array}$ & $\begin{array}{l}\text { Audit and feedback. } \\
\text { Before-after study. }\end{array}$ & $\begin{array}{l}\text { Intensive management. } \\
\text { Visual estimation or weighing. }\end{array}$ & $\begin{array}{l}\text { In hospital } 1: 1.52 \% \text { vs. } 0.96 \% \\
\text { In hospital } 2: 2.08 \% \text { vs. } 0.57 \%\end{array}$ & $\begin{array}{l}0.048 \\
<0.001\end{array}$ \\
\hline $\begin{array}{l}\text { Shields LE et al. } 2011 \\
\text { [41]. } \\
\text { USA (Dped). }\end{array}$ & $\begin{array}{l}5813 \text { (VD and CS) } \\
1 \text { unit; } 2009 .\end{array}$ & $\begin{array}{l}\text { In-centre simulation. } \\
\text { Before-after study. }\end{array}$ & $\begin{array}{l}\text { Simple PPH: blood loss }>500 \mathrm{ml} \text { for } \\
\text { VD or }>1000 \mathrm{ml} \text { for } \mathrm{CS} \text {; severe } \mathrm{PPH} \text { : } \\
\text { blood loss }>1500 \mathrm{ml} \text {. } \\
\text { Visual estimation or weighing. }\end{array}$ & $\begin{array}{l}\text { Simple PPH successfully treated: } 35 \% \\
\text { to } 82 \% \\
\text { Severe PPH successfully treated: } 11 \% \\
\text { to } 10 \%\end{array}$ & $\begin{array}{l}0.02 \\
\text { NS }\end{array}$ \\
\hline $\begin{array}{l}\text { Deneux-Tharaux C et al. } \\
2010 \text { [33]. } \\
\text { France (Dped). }\end{array}$ & $\begin{array}{l}146781 \text { (VD and } \\
\text { CS). } \\
105 \text { units; } 2006 .\end{array}$ & $\begin{array}{l}\text { Multifaceted } \\
\text { intervention. } \\
\text { RCT. }\end{array}$ & $\begin{array}{l}\text { Intensive management. } \\
\text { Visual estimation or measured. }\end{array}$ & $1.64 \%$ vs. $1.65 \%$ & NS \\
\hline $\begin{array}{l}\text { Audureau E et al. } 2009 \\
\text { [42]. } \\
\text { France (Dped). }\end{array}$ & $\begin{array}{l}1219 \text { (VD and CS). } \\
19 \text { units; 2002, } \\
2005 .\end{array}$ & $\begin{array}{l}\text { Multifaceted } \\
\text { intervention. } \\
\text { Before-after study. }\end{array}$ & $\begin{array}{l}\text { Intensive management. } \\
\text { Visual estimation or measured. }\end{array}$ & $0.80 \%$ vs. $0.86 \%$ & NS \\
\hline $\begin{array}{l}\text { Figueras } A \text { et al. } 2008 \\
\text { [50]. } \\
5 \text { countries in Latin } \\
\text { America (Dping). }\end{array}$ & $\begin{array}{l}2247 \text { (probably } \\
\text { VD). } \\
17 \text { units; 2003- } \\
2005 .\end{array}$ & $\begin{array}{l}\text { Training. } \\
\text { Before-after study. }\end{array}$ & $\begin{array}{l}\text { PPH mentioned in clinical records. } \\
\text { Not detailed. }\end{array}$ & $\begin{array}{l}\text { At } 3 \text { months: } 12.7 \% \text { vs. } 6.9 \% \\
\text { At } 12 \text { months: } 12.7 \% \text { vs. } 5.0 \%\end{array}$ & $\begin{array}{l}<0.05 \\
<0.05\end{array}$ \\
\hline $\begin{array}{l}\text { Ducloy-Bouthors AS el } \\
\text { al. } 2008 \text { [70]. } \\
\text { France (Dped). }\end{array}$ & $\begin{array}{l}41992 \text { (VD and } \\
\text { CS). } \\
5 \text { units; 2004- } \\
2006 .\end{array}$ & $\begin{array}{l}\text { Training. } \\
\text { Before-after study. }\end{array}$ & $\begin{array}{l}\text { Blood loss } \geq 500 \mathrm{ml} \\
\text { Not detailed. }\end{array}$ & $0.88 \%$ vs. $1.25 \%$ & NS \\
\hline
\end{tabular}

Dped, Developed economies; Trans, Economies in transition; Dping, Developing economies; VD, vaginal delivery; CS, C-section; NS, not significant 


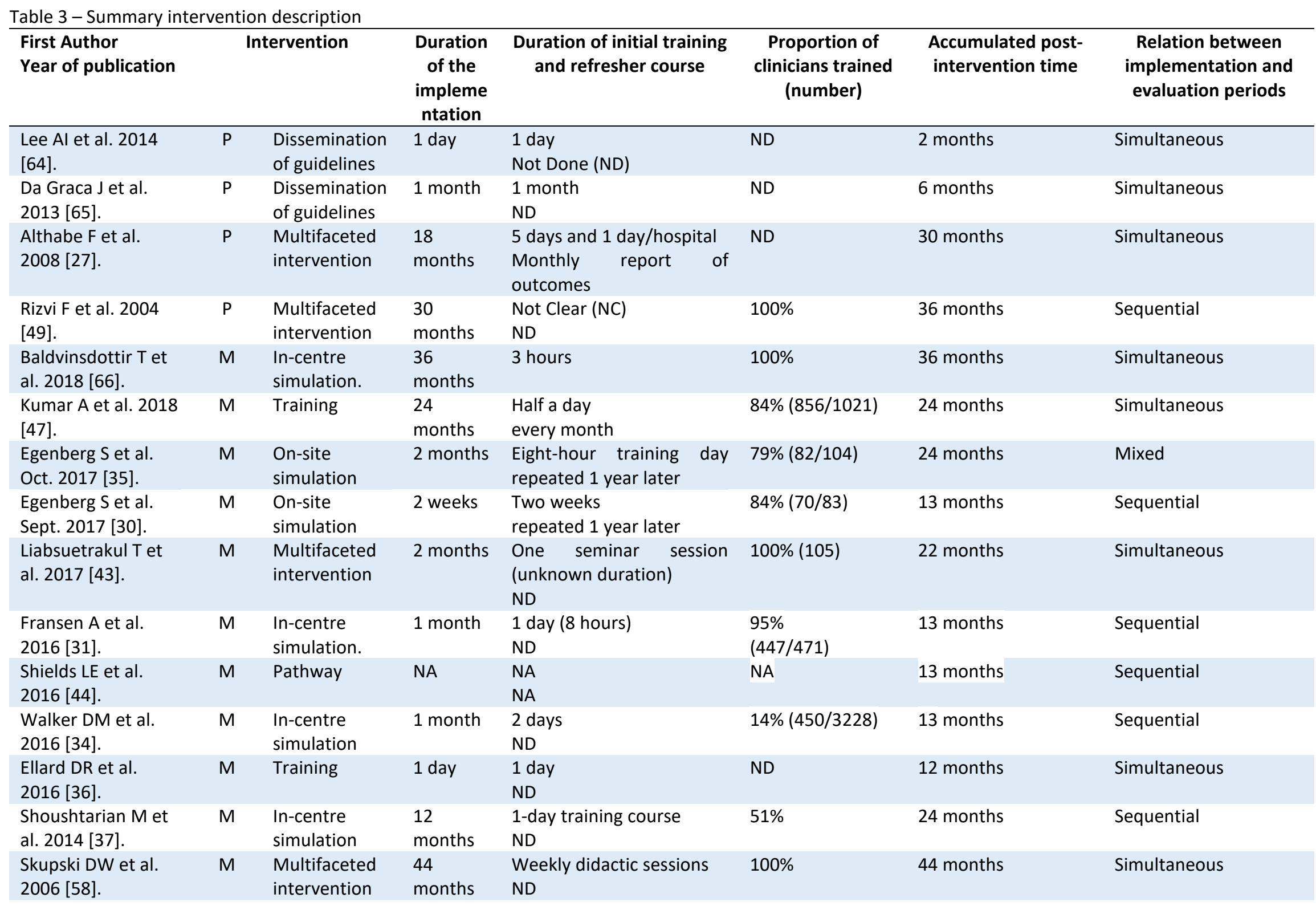




\begin{tabular}{|c|c|c|c|c|c|c|c|}
\hline $\begin{array}{l}\text { Hamm RF et al. } \\
2018 \text { [67]. }\end{array}$ & $\begin{array}{l}P \text { and } \\
M\end{array}$ & $\begin{array}{l}\text { Multifaceted } \\
\text { intervention }\end{array}$ & 4 months & $\begin{array}{l}\text { Unknown } \\
\text { ND }\end{array}$ & ND & 6 months & Sequential \\
\hline $\begin{array}{l}\text { Nelissen E et al. } \\
2017 \text { [46]. }\end{array}$ & $\begin{array}{l}\mathrm{P} \text { and } \\
\mathrm{M}\end{array}$ & $\begin{array}{l}\text { On-site } \\
\text { simulation }\end{array}$ & 1 month & $\begin{array}{l}\text { Unknown } \\
\text { ND }\end{array}$ & $80 \%(8 / 10)$ & 15 months & Sequential \\
\hline $\begin{array}{l}\text { Nadisauskiene RJ et } \\
\text { al. } 2016 \text { [68]. }\end{array}$ & $\begin{array}{l}\mathrm{P} \text { and } \\
\mathrm{M}\end{array}$ & $\begin{array}{l}\text { Multifaceted } \\
\text { intervention }\end{array}$ & 4 months & $\begin{array}{l}\text { Training for } 2 \text { months } \\
\text { ND }\end{array}$ & ND & 12 months & Sequential \\
\hline $\begin{array}{l}\text { Einerson BD et al. } \\
2015 \text { [59]. }\end{array}$ & $\begin{array}{l}\mathrm{P} \text { and } \\
\mathrm{M}\end{array}$ & $\begin{array}{l}\text { Multifaceted } \\
\text { intervention }\end{array}$ & $\begin{array}{l}12 \\
\text { months }\end{array}$ & $\begin{array}{l}\text { ND } \\
\text { Periodic training for } \\
\text { incoming staff only }\end{array}$ & $100 \%$ & 40 months & Simultaneous \\
\hline $\begin{array}{l}\text { Shields LE et al. } \\
2015 \text { [28]. }\end{array}$ & $\begin{array}{l}\mathrm{P} \text { and } \\
\mathrm{M}\end{array}$ & $\begin{array}{l}\text { Audit and } \\
\text { feedback }\end{array}$ & 3 months & $\begin{array}{l}\text { Initial protocol diffusion } \\
\text { Monthly audit feedback }\end{array}$ & ND & 10 months & Mixed \\
\hline $\begin{array}{l}\text { Dupont C et al. } \\
2014 \text { [39]. }\end{array}$ & $\begin{array}{l}\mathrm{P} \text { and } \\
\mathrm{M}\end{array}$ & $\begin{array}{l}\text { Audit and } \\
\text { feedback }\end{array}$ & $\begin{array}{l}96 \\
\text { months }\end{array}$ & $\begin{array}{l}3 \text { hours } \\
\text { Every } 3 \text { months }\end{array}$ & $100 \%$ & 96 months & Simultaneous \\
\hline $\begin{array}{l}\text { Dumont A et al. } \\
2013 \text { [32]. }\end{array}$ & $\begin{array}{l}\mathrm{P} \text { and } \\
\mathrm{M}\end{array}$ & $\begin{array}{l}\text { Multifaceted } \\
\text { intervention }\end{array}$ & $\begin{array}{l}24 \\
\text { months }\end{array}$ & $\begin{array}{l}6 \text { days } \\
\text { Quarterly visits by a } \\
\text { trained external facilitator }\end{array}$ & ND & 36 months & Sequential \\
\hline $\begin{array}{l}\text { Lappen JR et al. } \\
2013 \text { [69]. }\end{array}$ & $\begin{array}{l}P \text { and } \\
M\end{array}$ & $\begin{array}{l}\text { Multifaceted } \\
\text { intervention }\end{array}$ & $\begin{array}{l}12 \\
\text { months }\end{array}$ & $\begin{array}{l}1 \text { month } \\
\text { ND }\end{array}$ & $100 \%$ & 18 months & Sequential \\
\hline $\begin{array}{l}\text { Markova V et al. } \\
2012 \text { [29]. }\end{array}$ & $\begin{array}{l}\mathrm{P} \text { and } \\
\mathrm{M}\end{array}$ & $\begin{array}{l}\text { On-site } \\
\text { simulation }\end{array}$ & $\begin{array}{l}48 \\
\text { months }\end{array}$ & $\begin{array}{l}\text { 2.5-hour training session } \\
\text { ND }\end{array}$ & $100 \%(156)$ & 48 months & Simultaneous \\
\hline $\begin{array}{l}\text { Sorensen BL et al. } \\
2011 \text { [45]. }\end{array}$ & $\begin{array}{l}P \text { and } \\
M\end{array}$ & Training & 2 days & $\begin{array}{l}2 \text { days } \\
\text { ND }\end{array}$ & ND & 3 months & Simultaneous \\
\hline $\begin{array}{l}\text { Dupont C et al. } \\
2011 \text { [40]. }\end{array}$ & $\begin{array}{l}\mathrm{P} \text { and } \\
\mathrm{M}\end{array}$ & $\begin{array}{l}\text { Audit and } \\
\text { feedback }\end{array}$ & $\begin{array}{l}48 \\
\text { months }\end{array}$ & $\begin{array}{l}3 \text { hours } \\
\text { Every } 3 \text { months }\end{array}$ & $100 \%$ & 48 months & Simultaneous \\
\hline $\begin{array}{l}\text { Shields LE et al. } \\
2011 \text { [41]. }\end{array}$ & $\begin{array}{l}\mathrm{P} \text { and } \\
\mathrm{M}\end{array}$ & $\begin{array}{l}\text { In-centre } \\
\text { simulation }\end{array}$ & 6 months & $\begin{array}{l}3 \text { months } \\
\text { ND }\end{array}$ & ND & 18 months & Sequential \\
\hline $\begin{array}{l}\text { Deneux-Tharaux C } \\
\text { et al. } 2010 \text { [33]. }\end{array}$ & $\begin{array}{l}\mathrm{P} \text { and } \\
\mathrm{M}\end{array}$ & $\begin{array}{l}\text { Multifaceted } \\
\text { intervention }\end{array}$ & 3 months & $\begin{array}{l}3 \text { hours for presentation of } \\
\text { guideline } \\
3 \mathrm{~h} \text { for peer review, ( } 3 \\
\text { months after initial } \\
\text { intervention) }\end{array}$ & $100 \%$ & 14 months & Simultaneous \\
\hline $\begin{array}{l}\text { Audureau E et al. } \\
2009 \text { [42]. }\end{array}$ & $\begin{array}{l}\mathrm{P} \text { and } \\
\mathrm{M}\end{array}$ & $\begin{array}{l}\text { Multifaceted } \\
\text { intervention }\end{array}$ & $\begin{array}{l}14 \\
\text { months }\end{array}$ & $\begin{array}{l}3 \text { hours } \\
\text { ND }\end{array}$ & $100 \%$ & 18 months & Sequential \\
\hline
\end{tabular}


2008 [50].

$P$ and Training

3 months 3 months

$100 \%$

15 months

Mixed

Ducloy-Bouthors AS P and Training

ND

ND

el al. 2008 [70]. $M$

ND

ND

Sequential

P, Prevention; M, Management; NA, Not applicable; ND, Not documented. Accumulated post-intervention time is defined as the sum of the implementation and the evaluation periods. 